becoming too difficult for many prosont-day managers, and by equipping themselves with the appropriate skills they stand a better chance of being effective at their job.

The assertion is often made that management is best taught by practising managers, that the material taught should be based on the lecturer's own experience and that management training is best carried out in industrial firms, using the experience of the firms and their em. ployees. But any manager's experience is necessarily limited by the type of activities he has been engaged on and the kind of situations he has had to face. It is doubtful whether such experience will always be valuable, or even relevant, when this manager and his trainees have to face different circumstances from those recorded in the past. The manager's claim to success does not precludo tho possibility that the same level of success, or even bettor results, could not have been attained by other methods than those he advocates. Moreover, the fact that firms call in industrial consultants, who are not necessarily more mature in years and industrial experience than the firm's own managers, is an admission that other approaches could bo holpful in controlling a changing environment. Resorting to management-training programmes within firms can lead to the worst kind of inbreeding, couplod with stifling of initiative and imagination; and even if his past experience is relevant, tho manager is rarely equipped with the skills required to impart his knowledge to others in a systematic fashion or to be an educator.

Industrial firms should re-examine the assumptions on which their management training schemes are based. It would be far better, according to Prof. Eilon, if they were to send their management trainees to a course at an academic institution and then subject them to a short course in the firms, the purpose of which would be to tell these young people about the work and structure of the companies, rather than to teach them their own brand of managemont.

The form of management eduoation at the university was also exarnined. Prof. Eilon is doubtful whether the undergradunto student is mature enough to approciato the implications and ramifications of the subject, and recommends that it should bo left to the postgraduate stage.

\title{
OBITUARIES
}

Prof. D. D. Woods, F.R.S.

Pzor. D. D. Woovs, who died on November 6, 1964, at the age of fifty-two, was the first holder of a chair of chemical microbiology in Britain.

Donald Devereux Woods was a student at 'Trinity Hall, Cambridge, and obtained first-class honours in both parts of the Natural Sciences Tripos. After graduation in 1933 he began research in the Sir William Dunn sehool of Biochemistry, Cambridgo, whore ho came under the influence of Sir Frederick Cowland Hopkins and also of Dr. Marjory Stephenson, and it was his association with the latter that led to the development of his interest in the biochemistry of micro-organisms. He obtained the degree of Ph.D. in 1937 and was awarded a Beit Memorial fellowship. He left Cambridge in 1939 to join the Medical Research Council Unit for Bacterial Chemistry at the Middlesex Hospital under the direction of Dr. (later Sir) Paul Fildos. During the Second World War he, togethor with other members of the Unit, was seconded to the Biology Section of the Chemical Defence Research Establishmont at Porton. After the War he was invited by Prof. (later Sir) Rudolph Peters to join the Biochemistry Department at Oxford, where he was appointed reader in microbiology in 1946 and Iveagh profossor of chomical microbiology on the endowment of this chair by Arthur Guinness, Son and Co., Ltd., in 1955. He remained at Oxford until tho time of his death. Tho lenves a wife and a daughter.

From the time he first began research, Woods worked on the biochomistry of micro-organisms. During his poriod at Cambridge, he was mainly concerned with amino-acid and energy metabolism of Olostridia and with mechunisms of hydrogon production in bacteria. When ho movod to the Medical Research Conncil Unit, he turned his attention to the nature of the substance present in yeast extract which antagonizes the antibacterial action of sulphnnilamide. His demonstration that this substance is $p$-aminobenzoic acid, a structural analogue of sulphanilarnide, first brought him international recognition. 'Togothor with Fildes, he then put forward the hypothesis that substances which are structural analogues of essential metabolites could inhibit the metabolism of the latter and so prevent growth. This hypothosis proved a great stimulus to research in the design of drugs as "metabolite anglogues" and, indeed, the hypothesis has to-day become one of the few principlos availablo for the rational develop- ment of chemotherapeutic agents. Woods was not able to participate in the early cxploitation of the idea, as he was seconded to work at Porton at that time. During the Second World War, workers in the United States showed that $p$-aminobenzoic acid forms part of the molecule of the growth factor folic acid.

When Woods was able to resumo academic research in Oxford, he showed that the sulphonamides inhibit the conversion of $p$-aminobenzoic acid to folic acid. Together with research students and colleaguos, he then began a series of investigations, using combinations of nutritional mutiant and enrymological techniques, to elucidate the biosynthetic functions of folic acid and vitamin $B_{12}$. Investigations of the nutritional requirements of bacteria mutants requiring folic acid or vitamin $B_{12}$ showed that both growth factors are involved in the synthesis of methionine from homocysteine. The inter-relationship of folic acid and $B_{12}$ proved to be highly complex and was unravelled in a series of papers culminating in three publications in the Septomber 1964 issue of the Biochemical Journal. Folic acid is converted to a methyl-derivative

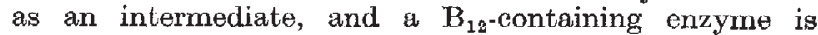
necessary for transfer of tho methyl group from folic acid to homocystcine. An alternative $\mathbf{B}_{12}$-independent pathway was discovered and proved to bo uniquely dependent on the triglutamate form of folic acid. The demonstration that some organisms can synthesize their methionine requirement without the medintion of $B_{12}$ while olhers have undergone a mutation to $\mathrm{B}_{12}$ dependency is of considorable evolutionary interest. In the course of these investigations on methionino synthesis, Woods also made one of the first observations of enzyme repression when ho found that growth of organisms in the presence of methionine results in loss of the formation of the homoeystoino mothylating system. The disentangling of this complox situation bears witness to Woods's skill, intellectual ability and unfailing patieneo.

Prof. Woods was a Fellow of Trinity College, Oxford, and in 1951 was clocted a Fellow of the Royal Society. He gave the first Marjory Stephenson Memorial Lecture of the Society for General Microbiology in 1953 and frequently took a major part in symposia and diseussions of that Society. He had a flair for the exposition of difficult biochemical topies, and his lectures were leavened with delightful touches of humour. It is a mattor of great, regrot that he did not live to deliver the Leeuwenhoele 
Lecture which he had been invited to give to the Royal Society in December 1964. Apart from his academic activities, Woods sat on many committees and advisory bodies dealing with microbiology and its application; he also carried out considerable editorial work for scientific journals. His many friends and colleagues will always remember his friendliness and enthusiasm for his subject; a long line of successful students will remember his kindly encouragement, advice and guiding hand. He led a full life in pursuit of his subject, and his death leaves a big gap in the ranks of both microbiologists and biochemists.

E. F. Gale

\section{Prof. L. W. Pollak}

Prof. L. W. Pollak, most widely known for his work in developing the photoelectric nucleus-counter, died in Dublin on November 24, 1964. He was born in Prague on September 23, 1888, and after a distinguished school and college career there was appointed to the staff of the German University in 1911. During the First World War he directed the meteorological service of the German Eleventh Army in the South Tyrol, and afterwards returned to the University, becoming professor of meteorology in 1927 and then director of the Observatories of Prague and Donnersberg.

Pollak's outlook was too liberal to please the Nazi régime, but his students made sure he learned of it when his name went on the list of disapproved persons. $\mathrm{He}$ was thus able to escape, and, after some months in London, found congenial employment in the newly formed Irish Meteorological Service, taking up duty at Foynes in December 1939. There he worked alongside Dr. M. Doporto, refugee from Spain, who died in September 1964. Pollak assisted in the teaching of the cadet forecasters, infecting them with his real enthusiasm for meteorology. He next proceeded to establish the Service's Climatological Division and to initiate its regular publications. In 1947, however, he welcomed the opportunity to regain his standing of professor, as head of the School of Cosmic Physies in the Dublin Institute of Advanced Studies. He quickly built the premises in Merrion Square into an important observatory. The number of students was small, but research continued in many sections of geophysics, while colleagues extended the scope of the School with sections for astronomy and cosmic rays. In 1955 it was the venue for the first International Symposium on Atmospheric Condensation Nuclei.

Pollak retired when seventy-five, but not to laze. $\mathrm{He}$ was much in demand as consultant and spent most of his last year assisting projects in the United States. It was, however, at his home that death came suddenly.

Pollak's lectures were prepared with meticulous care, and yet achieved the appearance of spontaneity, and included homely and topical references. Nearly two hundred papers bear his name, many dealing with the photoelectric nucleus counter, developed during his first years in Ireland. It had been the pioneer work on punchedcard techniques in climatology which had established Pollak's name earlier, and he was also largely responsible for the dissemination of Fuhrich's auto-correlation method of investigating periodicities. The only text-book bearing his name is Methods of Climatology, published in 1950, written in collaboration with V. Conrad, of Harvard University (formerly at Vienna). Many modern instruments incorporate Pollak's improvements: actinometers, balloon theodolites, kata-thermometers, dosimeters, tonometers: all received his attention, and several were the subjects of patents.

His first wife, Johanna, was a gifted linguist. She died in 1958. In 1962 he married Nessa Falconer, who survives him.
F. E. Dixon

\section{NEWS and VIEWS}

\section{Council for Scientific Policy}

The following have been appointed members of the Council for Scientific Policy: Sir Harrie Massey, Quain professor of physics, University College, London (chairman); Dr. J. B. Adams, director of the Culham Research Laboratory, Atomic Energy Authority; Prof. D. H. R. Barton, professor of organic chemistry, Imperial College of Science and Technology; Prof. P. M. S. Blackett, professor of physies, Imperial College of Science and Technology (also member of the Advisory Council on Technology); Prof. F. S. Dainton, professor of physical chemistry, University of Leeds; Sir Charles Dodds, Courtauld professor of biochemistry, University of London; Prof. K. C. Dunham, professor of geology, University of Durham ; Prof. B. H. Flowers, Langworthy professor of physics, University of Manchester; Sir Willis Jackson, professor of electrical engineering, Imperial College of Science and Technology; Dr. F. E. Jones, managing director, Mullards, Ltd.; Dr. J. C. Kendrew, deputy-chairman, Medical Research Council, Laboratory for Molecular Biology, Cambridge; Lord Rothschild, chairman, Shell Research; Sir Gordon Sutherland, Master of Emmanuel College, Cambridge; Prof. M. M. Swann, professor of zoology and dean of the Faculty of Science in the University of Edinburgh. The Council for Seientific Policy will replace the Advisory Council on Scientifie Policy and will advise the Secretary of State in the exercise of his responsibility for the formulation and execution of Government scientific policy. Among the issues which are expected to come before the Council will be the balance of scientific effort in the various fields for which the Secretary of State is responsible.

\section{Operational Research in the University of Birmingham :} Dr. S. Vajda

Dr. Steven VAJda has been appointed to the newly established chair of operational research in the Department of Engineering Production, University of Birmingham, as from January 22. Dr. Vajda, who was born in Budapest, and who graduated as a Doctor of Philosophy in the University of Vienna, has been head of the Mathematics Group in the Admiralty Research Laboratory at Teddington since 1952. He had previously been a lecturer in the Technical University of Berlin and held various actuarial appointments on the Continent and in Britain before joining the Civil Establishment of the Admiralty in 1944; he was later assistant director of physical research and assistant director of operational research in the Royal Naval Scientific Service. He has been a member of council of the Royal Statistical Society, chairman of the Department of Scientific and Industrial Research Sub-committee on Automatic Data Processing and chairman of the Programme Committee of the International Symposium on Mathematical Programming. His books on mathematical programming and the theory of games have been translated into French, German, Japanese and Russian.

\section{The Rockefeller Institute :}

Prof. C. Pfaffmann

Dr. C. Pfaffmann has been appointed vice-president and professor of the Rockefeller Institute, where he will be responsible for the development of a broad programme of graduate teaching and research in the behavioural sciences, with emphasis on the relations of the natural and social sciences. Dr. Pfaffmann graduated from Brown 